\title{
Using Educational Robotics as an Instruction Tool for Teaching the Omani Social Studies Curriculum
}

\author{
Ahmed Al Rabaani* \\ Sultan Qaboos University - College of Education, PO Box 32, Al Khod 123 - Muscat - Oman \\ Muna Al Na'aimi \\ Social Studies Teacher, Ministry of Education
}

\begin{abstract}
The study aimed to explore the possibility of using educational robotics as instruction tools for teaching the Omani social studies curriculum. Focusing on this area is driven by lack of literature about implementation of robotics in teaching social studies. A questionnaire consisting of 38 items covering five pedagogical domains was administered to 201 male and female Omani social studies teachers. It was found that male and younger social studies teachers are more positively predisposed toward the adoption and use of educational robotics, but the results revealed that Omani social studies teachers in general lack knowledge and skills in educational robotics, and they think that the current school environment does not support its implementation. Correspondingly, they strongly recommended providing training programs about educational robotics and developing the school environment to facilitate the adoption and use of educational robotics.
\end{abstract}

Keywords: Educational robotics, Oman, pedagogy, secondary school, social studies, teaching

DOI: $10.7176 / \mathrm{JEP} / 13-1-02$

Publication date: January $31^{\text {st }} 2022$

\section{Introduction}

In the increasingly globalized world economy and educational framework, national educational systems are increasingly standardized and compelled to raise standards to enhance the quality of learning environment. New technological solutions can, when applied effectively, greatly enhance the teaching and learning process, empowering students to achieve learning outcomes and be equipped with the knowledge and skills necessary for the $21^{\text {st }}$ century. Modern digital technologies can address many pedagogical and systematic educational issues, such as reducing costs and facilitating access to learning resources, and improving classroom knowledge acquisition by shaping more conducive learning environments that attract student attention and engagement. Educational robotics (ER) is considered as one of the tools that has been widely acknowledged around the globe as a promising avenue for future pedagogical applications.

\section{Theoretical Framework}

ER technology is part of the fourth industrial revolution, which has improved greatly in quality and variety over recent decades, and which is now able to seriously contribute to educational purposes and school requirements. ER implementation in schools has increased rapidly in some developed country contexts, due to features such as attractiveness for students and teachers, providing practical experiences, linking classroom with field work, and enabling students to understand studied concepts and applying knowledge in real situations across time, place, and context (Edutopia, 2012). It also provides variety of opportunities to develop student skills for the $21^{\text {st }}$ century, particularly to enhance innovation, problem solving, critical thinking, task management, and higher thinking skills (Alimisis, 2013; Eguchi, 2014; Daniela \& Lytras, 2019; Ponce et al, 2019). In addition, it enhances students' understanding of complicated and abstract concepts, promotes positive attitudes, fosters motivation, and develops problem-solving and computational thinking skills (Eguchi, 2014; Xia \& Zhong, 2018; Alimisis, 2018). It can facilitate the development of students' technical and soft skills (Damaševicius, Narbutaite, Plauska, \& BlaŽauskas, 2017). It also attracts student attention and interaction (Saerbeck, Schut, Bartneck, \& Janse, 2010; Park, Kim \& Del Pobil, 2011; Benitt, 2012), and recall abilities (Szafir \& Mutlu, 2012).

These features led to the relatively rapid deployment of robotics in teaching science, technology, engineering, and mathematics (STEM) subjects (Mataric, 2004; Janssen, van der Wal, Neerincx, \& Looije, 2011). Later on, it began gaining traction in other subjects such as history (Bravo, Hurtado, \& González, 2021), languages (Saerbeck et al., 2010), and other subjects, activities, and tasks (Looije, Neerincx, \& de Lange, 2008). Despite its inherently attractive features, the literature shows that its implementation is not smooth or even, and many challenges are encountered during practical implementation, similar to the implementation of any new technology or program.

According to the literature, the implementation of robotics is significantly affected by teachers' level of knowledge, skills, and attitudes toward them. Thus, introducing robotics to schools requires not only providing robotics but also making the transformation from ordinary or traditional teaching methods to digitized ones. This requires structured and well-organized implementation to ensure contribution to enhance student achievement, 
attitudes, and motivation (Eguchi, 2014; Alimisis, 2018; Xia \& Zhong, 2018).

Thus, the ER implementation requires the preparation of teachers and school environments, aside from students themselves, to support and enable effective usage; otherwise, a lack of teacher preparation and prerequisite school facilities will lead to limited use in practice, and unwillingness or resistance, especially if teachers lack necessary knowledge and skills, time availability, and technical (robotics) support (Mondada, Chevalier, \& Riedo, 2016; Mcclure et al., 2017; Negrini, 2020; Tang, Tung, \& Cheng, 2020; Y1ldırım, 2021).

Fundamental limitations to adoption and use that must be addressed by implementation strategies include teachers' lack of self-confidence in such use, particularly among those who are not interested in using technology, or who feel unqualified to use it, which leads to avoidance at the classroom level (Sangkawetai, Neanchaleay, Koul, \& Murphy, 2020). Also, some studies found that introducing robotics in the absence of a training program negatively affects teachers' attitudes and beliefs concerning the added value of using these robotics (Reich-Stieber \& Eyssel, 2016). Other studies showed that teachers who are unprepared for using ER show resistance to use it because they lack background knowledge about its pedagogical value and practical relevance, particularly in relation to achieving curriculum goals (Sisman \& Kucuk, 2019; Schina, Valls-Bautista, Borrull-Riera, Usart, \& Esteve-González, 2021).

Based on the experiences of many education systems and studies, providing training programs is very crucial to achieve transformation from traditional to digital teaching methods and avoid teacher resistance to such adoptions. Some studies found that teachers who are not using ER, or who avoid using it, admit that their behavior is primarily caused by their lack of knowledge and skills. and they highly stress the need for professional training programs to develop their related knowledge and skills so they can deliver ER effectively and confidently (Williams, 2017). Some studies found that training programs have resulted in promoting positive attitudes, selfconfidence, and greater interest to use ER (Li, Li, \& Franklin, 2016; Mondada et al., 2016; Castro et al., 2018; MacDonald, Huser, Sikder, \& Danaia, 2020; Sangkawetai et al., 2020). Providing training programs develops teachers' knowledge and skills and enables them to live up to expectations and satisfy the requirements of introducing these robotics in their lessons and activities (Sisman \& Kucuk, 2019). Training also improves teachers' knowledge and skills about connecting the use of robotics with pedagogical theory and constructivism (Tocháček, Lapeš, \& Fuglík, 2016).

The current study focusses on possibilities of using educational robotics as instructional tools in teaching the Omani social studies curriculum. Focusing on this area is driven by lack of literature about implementation of robotics in teaching social studies, and by global and local attitudes toward expansion of using robotics in all school subjects in order to benefit from its advantages. Focusing on using robotics in the social studies curriculum is very important because this subject is directly concerned with fostering students' knowledge, skills, attitudes, and values related to human and nature phenomenon and interactions between them. These phenomena and their interactions include a lot of abstract concepts and complicated process that can potentially be explained more effectively using robotics. Also, focusing on the Omani experiences of robotics implementation sheds light on a largely unerxplored pedagogical context, to help inform the decision making and strategies of curriculum designers and educators.

\section{Research Questions}

- What is the awareness of Omani social studies teachers about ER and do they implement it?

- What is the knowledge and skills readiness of Omani social studies teachers related to using ER in lessons?

- Do school learning environments support ER classroom implementation?

- Do Omani social studies teachers believe that social studies curriculum design supports ER implementation?

- What are Omani social studies teachers' views about suggestions to enhance implementation of the ER in their lessons?

- Do Omani social studies teachers' knowledge, skills, and views about using ER differ according to their gender or experience?

\section{Study Objectives}

To examine the level of Omani social studies teachers' knowledge and skills about using ER.

To investigate the current readiness of the school learning environment for ER implementation.

To identify challenges facing ER implementation in social studies teaching.

\section{Method \\ Sample}

There was a total of 3270 Omani social studies teachers in the 2020/2021 academic year. The study sample consisted of 201, comprising 117 males (58.2\%) and 84 females (41.8\%), drawn from different Omani 
governorates. The sample corresponded to $6.15 \%$ of the total study population. Table 1 shows the sample distribution according to teachers' gender and experience.

Table 1: Participant gender and experience characteristics

\begin{tabular}{|c|l|c|c|}
\hline \multicolumn{2}{|c|}{ Variable } & Frequency & \% \\
\hline \multirow{4}{*}{ Gender } & Male & 117 & 58.2 \\
\cline { 2 - 4 } & Female & 84 & 41.8 \\
\cline { 2 - 4 } & Total & 201 & 100.0 \\
\hline \multirow{2}{*}{$\begin{array}{c}\text { Experience } \\
\text { (years) }\end{array}$} & $1-5$ & 75 & 37.3 \\
\cline { 2 - 4 } & $6-10$ & 34 & 16.9 \\
\cline { 2 - 4 } & $>11$ & 92 & 45.8 \\
\cline { 2 - 4 } & Total & 201 & 100.0 \\
\hline
\end{tabular}

\section{Instrument}

The data was collected using a quantitative questionnaire, consisting of 38 items divided into five domains, developed based on previous literature (Mondada et al., 2016; Mcclure et al., 2017; Negrini, 2020; Tang, 2020; Y1ldırım, 2021). The validity of the questionnaire was examined by a panel of judges from the College of Education at Sultan Qaboos University and the Ministry of Education. The reliability of the questionnaire was ascertained by piloting it with a sample of the social studies teachers, and it achieved a Cronbach's alpha coefficient of 0.915 , indicating high validity. The pilot study results were included in the final analysis, as no changes to the instrument were necessary after reviewing the outcomes of the pilot study.

\section{Results}

What is the awareness of Omani social studies teachers about ER and do they implement it?

Table 2 shows that the majority (84.7\%) of Omani social studies teachers have heard about ER, but the majority $(94.5 \%)$ of them have never received training programs about its use. Participants tried to develop their ER knowledge autonomously, through reading books and articles $(82.6 \%)$, multimedia $(79.1 \%)$, and attending symposiums and conferences (69.2\%). However, the absence of training significantly limited its use in their lessons, and $89.6 \%$ reported that they had never used it in their classrooms.

Table 2: Social studies teachers' answers related to their awareness of ER

\begin{tabular}{|l|l|c|c|}
\hline \multicolumn{1}{|c|}{ Questions } & Answer & Frequency & Percent \\
\hline \multirow{2}{*}{ Have you heard about ER? } & No & 31 & 15.3 \\
\cline { 2 - 4 } & Yes & 171 & 84.7 \\
\cline { 2 - 4 } & Total & 201 & 100 \\
\hline \multirow{2}{*}{ Have you received any training programs about ER } & No & 190 & 94.5 \\
\cline { 2 - 4 } & Yes & 11 & 5.5 \\
\cline { 2 - 4 } & Total & 201 & 100 \\
\hline \multirow{2}{*}{$\begin{array}{l}\text { Have you ever tried to develop your knowledge about ER } \\
\text { from books or articles? }\end{array}$} & No & 35 & 17.4 \\
\cline { 2 - 4 } & Yes & 166 & 82.6 \\
\cline { 2 - 4 } & Total & 201 & 100 \\
\hline \multirow{2}{*}{$\begin{array}{l}\text { Have you ever tried to develop your knowledge about ER } \\
\text { from multimedia such as YouTube etc.? }\end{array}$} & No & 42 & 20.9 \\
\cline { 2 - 4 } & Yes & 159 & 79.1 \\
\cline { 2 - 4 } & Total & 201 & 100 \\
\hline \multirow{2}{*}{$\begin{array}{l}\text { Have you tried to develop your knowledge about ER } \\
\text { through attending symposium and conferences? }\end{array}$} & No & 62 & 30.8 \\
\cline { 2 - 4 } & Yes & 136 & 69.2 \\
\cline { 2 - 4 } & Total & 201 & 1005 \\
\hline \multirow{2}{*}{ Have you ever used ER in your lessons? } & No & 180 & 89,6 \\
\cline { 2 - 4 } & Yes & 21 & 10,4 \\
\cline { 2 - 4 } & Total & 201 & 100 \\
\hline
\end{tabular}

What is the knowledge and skills readiness of Omani social studies teachers related to using ER in lessons? Table 3 shows that Omani social studies teachers have a low level of knowledge and skills of using ER. They showed low level of knowledge about how to use it in their lessons and low level of knowledge of using different types ER programs. They also had low level of knowledge about using it in exams and classroom activities. They also indicated that they cannot use it in lessons without technical support. Finally, they have a low level of managing the use of ER in classroom. 
Table 3: Means and standard deviations of teacher knowledge and skills

\begin{tabular}{|l|c|c|c|}
\hline \multicolumn{1}{|c|}{ Item } & Mean & SD & Level \\
\hline Level of knowledge about features of ER & 2.78 & 0.86 & Average \\
\hline Level of knowledge about using of ER in lessons & 2.52 & 0.83 & Low \\
\hline Level of knowledge of programs usable through ER & 2.42 & 0.92 & Low \\
\hline Level of designing programs that can be used by ER & 2.14 & 0.87 & Low \\
\hline Level of knowledge about types of ER & 2.17 & 0.86 & Low \\
\hline Level of knowledge about using ER in exams & 1.81 & 0.74 & Low \\
\hline Level of knowledge about using ER in classroom activities & 1.91 & 0.73 & Low \\
\hline Ability to use EE without need a technical support & 2.23 & 0.83 & Low \\
\hline Skill in using ER in any lessons & 2.37 & 0.76 & Low \\
\hline Managing class effectively during using ER & 2.40 & 0.78 & Low \\
\hline Average & 2.27 & 0.81 & \\
\hline
\end{tabular}

Do school learning environments support ER classroom implementation?

Table 4 shows that the current learning environment in Omani schools does not support ER implementation in general, and in social studies lessons in particular. It revealed that students lack computer skills to enable them to use ER. They are also unable to understand the English language materials of the ER, and lack skills of using different ER programs in a safe and competent manner. The results also indicated that schools lack facilities to support ER implementation, such as a shortage of ER per se, a lack of technical support, low internet speeds, and classroom and lab design issues.

Table 4: Means and standard deviations of school learning environment support of ER implementation

\begin{tabular}{|c|c|c|c|}
\hline Items $=\mathbf{- 0 9 8 7 6 5 4}$ & Mean & SD & Level \\
\hline \multicolumn{4}{|l|}{ Student's skills in ER } \\
\hline Students have computer skills that enable us to use ER & 2.35 & 0.78 & Low \\
\hline Students are skillful to use ER in a safety manner & 2.28 & 0.76 & Low \\
\hline $\begin{array}{l}\text { Students can easily understand English language of ER during preparing lessons } \\
\text { and applying it in the classroom }\end{array}$ & 2.51 & 0.81 & Low \\
\hline Students have the ability to deal with the different ER programs & 1.98 & 0.98 & Low \\
\hline Average & 2,28 & 0,75 & Low \\
\hline \multicolumn{4}{|l|}{ School facilities } \\
\hline Schools have enough number of ER & 1.64 & 0.78 & Low \\
\hline Technical support available in schools every time & 1.44 & 0.65 & Low \\
\hline Schools have high speed internet that enable to use ER & 2.16 & 0.66 & Low \\
\hline It easy to book ER when teachers want to use it in their lessons & 2.01 & 0.53 & Low \\
\hline School's labs and classroom design support using ER in a safe manner & 1.99 & 0.69 & Low \\
\hline Number of students in classroom is appropriate to use ER & 1.57 & 0.80 & $\mathrm{X}$ \\
\hline It easy to take or move ER from one classroom to another & 1.89 & 0.98 & $\mathrm{X}$ \\
\hline Average & 1.81 & 0.57 & \\
\hline
\end{tabular}

Do Omani social studies teachers believe that social studies curriculum design supports ER implementation?

Table 5 shows that the design of the content of the current social studies curriculum moderately supports using of ER, thus, the social studies teachers' think that the ER cannot be implemented in all of their lessons. Also, they have negatively beliefs about the use of ER as an evaluation tool. Finally, they have negatively views concerning the duration of lessons supporting ER implementation.

Table 5: Means and standard deviations of social studies curriculum design supporting ER implementation

\begin{tabular}{|l|c|c|c|}
\hline \multicolumn{1}{|c|}{ Items } & Mean & SD & Level \\
\hline ER can be implemented in all topic of social studies textbooks & 2.95 & 0.75 & Average \\
\hline Context of social studies content and activities encourage using ER & 2.83 & 0.68 & Average \\
\hline $\begin{array}{l}\text { ER could be used as a method to evaluate students' achievement in social } \\
\text { studies }\end{array}$ & 2.44 & 0.83 & Low \\
\hline Duration of social studies lessons support using ER & 1.91 & 1.00 & Low \\
\hline Average & 2.53 & 0.67 & Low \\
\hline
\end{tabular}

What are Omani social studies teachers' views about suggestions to enhance implementation of the ER in their lessons?

Table 6 shows that the social studies teachers strongly support suggestions that enhance implementation the ER. 
They strongly recommend increasing the number of ER tools used in schools, providing ER that supports Arabic language, technical support, and training programs. They also strongly stress the need to develop social studies curriculum to support requirement of ER and IT implementation. Also, providing user guides and funding for implementing ER would be welcomed.

Table 6: Means and standard deviations of suggestions to enhance ER implementation

\begin{tabular}{|l|c|c|c|}
\hline \multicolumn{1}{|c|}{ Items } & Mean & SD & Level \\
\hline Increase the number of ER in schools & 4.61 & 0.76 & \\
\hline Provide ER that support Arabic language & 4.61 & 0.72 & \\
\hline Provide technical support to use ER & 4.60 & 0.76 & \\
\hline Provide training programs to develop teachers ER using knowledge and skills & 4.42 & 0.73 & \\
\hline $\begin{array}{l}\text { Develop social studies curriculum to support the requirement of using ER } \\
\text { and IT }\end{array}$ & 4.70 & 0.72 & \\
\hline Provide ER using guide for teachers & 4.70 & 0.69 & \\
\hline Providing funding to implement ER & 4.74 & 0.68 & \\
\hline \multicolumn{1}{|c|}{ Average } & 4.62 & 0.66 & \\
\hline
\end{tabular}

Do Omani social studies teachers' knowledge, skills, and views about using ER differ according to their gender or experience?

- Gender

Table 7 shows significant differences between male and female Omani social studies teachers regarding ER implementation in their lessons, with male teachers displaying a more positive disposition in all domains except domain 3.

Table 7: T-test results for gender

\begin{tabular}{|c|c|c|c|c|c|c|}
\hline Domains & Sex & Mean & Std & $\mathbf{t}$ & df & Sig. \\
\hline \multirow[t]{2}{*}{ Awareness of ER } & Male & 58.11 & 21.84 & 2.385 & 199 & .018 \\
\hline & Female & 49.20 & 31.14 & 2.255 & 139.524 & \\
\hline \multirow{2}{*}{$\begin{array}{l}\text { Level of knowledge and skill of ER } \\
\text { implementation }\end{array}$} & Male & 2.46 & .516 & 4.944 & 199 & .000 \\
\hline & Female & 2.02 & .7338 & 4.676 & 139.973 & \\
\hline \multirow[t]{2}{*}{ Schools' readiness to implement ER } & Male & 1.91 & .509 & 2.073 & 199 & .039 \\
\hline & Female & 2.07 & .617 & 2.009 & 157.051 & \\
\hline \multirow{2}{*}{$\begin{array}{l}\text { Social studies curriculum design } \\
\text { supports ER implementation }\end{array}$} & Male & 2.55 & .579 & .686 & 199 & .493 \\
\hline & Female & 2.49 & .797 & .652 & 143.078 & \\
\hline \multirow{2}{*}{$\begin{array}{l}\text { Suggestions to enhance ER } \\
\text { implementation in social studies } \\
\text { lessons }\end{array}$} & Male & 4.75 & .516 & 3.287 & 199 & .001 \\
\hline & Female & 4.44 & .797 & 3.073 & 132.022 & . \\
\hline
\end{tabular}

\section{- Experience}

Table 8 shows that there is a statistically significant difference between social studies teachers due to their level of experience in all domains. Using Scheffe test showed that those who had 1-5 years' experience were more aware about ER, and were more equipped with knowledge and skills. They also have more negative beliefs about the suitability of the current school environment and current social studies curriculum to apply ER, and support suggestions that enhance ER implementation. 
Table 8: ANOVA results for experience

\begin{tabular}{|c|c|c|c|c|c|}
\hline Variable & Sum of Squares & df & Mean Square & $\mathbf{F}$ & Sig. \\
\hline \multicolumn{6}{|c|}{ Awareness of ER } \\
\hline Between groups & $21,859.605$ & 2 & $10,929.802$ & 18.360 & .000 \\
\hline Within groups & $117,869.527$ & 198 & 595.301 & & \\
\hline Total & $139,729.132$ & 200 & & & \\
\hline \multicolumn{6}{|c|}{ Level of knowledge and skill of ER implementation } \\
\hline Between groups & 10.907 & 2 & 5.453 & 14.574 & .000 \\
\hline Within groups & 74.089 & 198 & .374 & & \\
\hline Total & 84.996 & 200 & & & \\
\hline \multicolumn{6}{|c|}{ Schools' readiness to implement ER } \\
\hline Between groups & 12.991 & 2 & 6.496 & 25.635 & .000 \\
\hline Within groups & 50.172 & 198 & .253 & & \\
\hline Total & 63.164 & 200 & & & \\
\hline \multicolumn{6}{|c|}{ Social studies curriculum design supports ER implementation } \\
\hline Between groups & 10.278 & 2 & 5.139 & 12.459 & .000 \\
\hline Within groups & 81.668 & 198 & .412 & & \\
\hline Total & 91.946 & 200 & & & \\
\hline \multicolumn{6}{|c|}{ Suggestion to enhance ER implementation in social studies lessons } \\
\hline Between groups & 3.027 & 2 & 1.514 & 3.518 & .032 \\
\hline Within groups & 85.197 & 198 & .430 & & \\
\hline Total & 88.225 & 200 & & & \\
\hline
\end{tabular}

\section{Discussion}

The results revealed that ER implementation in teaching social studies in Oman is straggling due to many challenges, including a lack of teachers' skill and knowledge, materials, time, technical support, high-speed internet, and ER programs; and the language of robotics technology platforms and learning materials. These results support previous studies which found that ER implementation is still not well integrated in schools (Eguchi, 2014; Mondada et al., 2016). These reasons behind these challenges are similar to what has been found by many studies: lack of knowledge and skills (Goode \& Margolis, 2011; Mondada et al., 2016; Mcclure et al., 2017; Sisman \& Kucuk, 2019; Negrini, 2020; Tang, 2020; Y1ldırım, 2021), high cost of robotics (Cruz-Martin, Fernández-Madrigal, Galindo, González-Jiménez, Stockmans-Daou, \& Blanco-Claraco, 2012; Kradolfer, Dubois, Riedo, Mondada, \& Fassa, 2014), lack of learning materials (Mubin, Stevens, Shahid, Al Mahmud, \& Dong, 2013), lack of skills and lack of time (Mondada et al., 2016), shortage of experience (Vilorio, 2014), robotics languages (Newley, Deniz, Kaya, \& Yesilyurt, 2016), and managing robotic use (Loncomilla, Ruiz-del-Solar, \& Martínez, 2016).

The reasons behind these challenges may be due to ER still not being popular or widespread in teaching the socials studies curriculum, and its application in Oman is still mainly in STEM subjects. Consequently, attention to other subjects such social studies may not receive serious attention from education decision makers in the Omani education system, from the curriculum to school and classroom levels. It would also be prohibitively expensive to provide training programs to thousands of Omani teachers in various subjects, and would take a lot of time and resources from conventional, on-going educational services. However, according to the literature, ER implementation must be preceded by training programs to ensure development of teachers' knowledge, skills (Li et al., 2016; Mondada et al., 2016; Castro et al., 2018; MacDonald et al., 2020; Sangkawetai et al., 2020).

Aside from direct practical benefits, such training also promotes their attitudes, beliefs, and abilities to link technological tools with learning theory and practice, which reduces resistance and facilitates successful adoption (Tochácek et al., 2016; Sisman \& Kucuk, 2019). Thus, it strongly recommended that teacher training programs should take action in the area of developing teacher knowledge and skills in new technological products, which will render it progressively easier to train them during preparation programs, rather than in services. Also, companies that produce such robotics need to provide online free training programs and support through multimedia resources, to demonstrate how to use tools. The Ministry of Education needs to provide approved materials on its website that help teachers to develop their knowledge and skills about using ER.

The results also explain that Omani social studies teachers are highly concerned about the implementation of technology in their lessons, and the majority of them tried to develop their knowledge about ER through reading books, articles, attending symposiums and conferences, and using multimedia resources. Such results support literature which showed that teachers' attitudes and concerns are curial for effective introduction and use of ER in schools (Negrini, 2020).

The results also indicated that Omani schools lack facilities that support ER implementation, such as students' lack knowledge and skills in using ER, difficulties in understanding English language materials, a shortage of ER 
equipment, a lack of technical support, classroom design not being germane to ER implementation, and low internet speeds. Such shortcomings limit the practical scope for ER application, and sometimes prevent implementation altogether in social studies lessons. These results support previous studies which showed that such challenges reduce ER use (De Koning \& Tabbers, 2011; Lu, Kang, Huang, \& Black, 2011).

The findings also explain that the current social studies curriculum does not support ER implementation due to the nature of content and activities design and shortage of time, with the limited number of lessons and vast content of the curriculum inhibiting the time-intensive deployment of ER; essentially, the limited timetable of lessons and the compelling curriculum focus on examinations causes ER to be perceived as an impractical luxury, which has been found to be a common barrier to effective ER deployment (Blikstein, 2013; Mubin et al., 2013; Mondada et al., 2016).

Table 6 shows that the social studies teachers strongly support suggestions that promote ER implementation in their lessons, such as providing training programs, increasing the number of ER in schools, providing user guides, developing the social studies curriculum for more ER integration, providing technical support, and providing ER platforms with Arabic language materials. These results reflect the high concern and interest of teachers about benefiting from ER to enhance learning environment, and solving problems causing low achievement among students in social studies, affirming previous studies (Al Shikali, 2013; Al Kalbani, 2016; AlDayri \& Al Rabaani, 2019; Al-Rabaani, \& Al-Wahaibi, 2019). It also reflects their positive attitudes towards applying technology in their lessons, as some previous studies showed (Al-Rabaani, 2008; Al Masrori, 2013; Al Madi, 2014).

The results indicated differences between social studies teachers according to their gender and experience. Male teachers had higher awareness of ER, level of knowledge and skills, and support to develop the social studies curriculum with more ER compared to their female counterparts, who were less optimistic about school readiness to implement ER. Such results could be due to that male teachers seemed to be more interested in applying technology and following new products due to sharing experiences between each other, and have more free time to learn about such things due to cultural factors in Oman (such as female teachers having more extensive family responsibilities). Also, the results showed that those who have lower experience between (1-5 years) have better knowledge and attitudes toward ER implementation, but they have strongly negative views about schools and curriculum potential to support using ER.

The results of this study differ from those of Kim, Choi, and Baek (2014), who found no differences in ER readiness according to gender and age. However, they affirm the findings of Reich-Stieber and Eyssel (2016), who also found differences according to gender and experience.

Overall, the results indicate that ER implementation in teaching social studies in Omani schools faces many challenges that need be addressed by decision makers in the Ministry of Education. These challenges limit or prevent effective ER implementation. Addressing these challenges needs urgent action, because Oman currently lags behind international norms in the application of ER in schools.

\section{Conclusion}

The study findings showed that Omani social studies teachers lack knowledge and skills related to ER implementation in their lessons, but that Omani schools are relatively well prepared to support ER implementation. Thus, it can be concluded that despite ER availability in Oman's schools, effective implementation is mainly limited because teachers cannot use it due to their lack of skills. Consequently, there a need for huge effort to provide comprehensive ER technological infrastructure and support, including Arabic language user guides and learning content, and to enhance the learning environment and support implementing ER in teaching social studies by empowering teachers with training in prerequisite technical and pedagogical skills related to ER.

\section{Acknowledgments}

We would like to thank all Omani social studies teachers who participated in this study.

\section{Future Research Direction}

Future studies can address the social studies' teachers' preparing programs and in service training regarding the development of their knowledge, attitudes and skills about the implementation of ER.

\section{References}

Al Dayri H \& Al-Rabaani A .(2019). Spatial thinking skills acquisition and textbook inclusion for female 10thgrade social studies students in Oman. Journal of Education and Practice, 10(27):86-89. https://doi.org/10.7176/JEP

Al Kalbani M .(2016). Inclusion of geomorphological concepts in social studies textbooks (5-10) grades, and students acquisition of them. MA thesis. Muscat: Sultan Qaboos University.

Al Madi M. (2014). Possibilities to apply google earth in teaching social studies in basic and post basic education 
in Oman from point view of social studies teachers. MA thesis. Muscat: Sultan Qaboos University.

Al Masrori F .(2013). Social studies teachers acquisition of information and communication technology competencies. MA thesis. Muscat: Sultan Qaboos University.

Al Shikali A .(2013). Level of Omani students' acquisition of geographical science process skills. MA thesis. Muscat: Sultan Qaboos University.

Alimisis D.( 2013). Educational robotics: open questions and new challenges. Themes in Science and Technology Education, 6(1):63-71.

Alimisis D .(2018). Teacher training in educational robotics: the ROBOESL Project paradigm. Technology, Knowledge and Learning, 24:279-290. https://doi.org/10.1007/s10758-018-9357-0

Al-Rabaani A \& Al-Wahaibi F.( 2019). Female students' achievement using Edmodo in the eleventh -grade economic geography curriculum in Oman, Journal of Technology and Information Education, 11(1): 38-46. https://doi.org/10.5507/jtie.2019.003

Al-Rabaani A (2008). Attitudes and skills of Omani teachers of social studies to the use of computers in instruction. International Journal of Education and Development Using Information and Communication Technology, 4(4): 15-34.

Benitti FBV .(2012). Exploring the educational potential of robotics in schools: a systematic review. Computers and Education 58:978-988.

Blikstein P .(2013). Digital fabrication and 'making' in education: the democratization of invention. In J WalterHerrmann \& C Büching (eds). FabLabs: of machines, makers, and inventors (pp. 203-221). Bielefeld: Transcript Publishers. https://doi.org/10.14361/transcript.9783839423820.203

Bravo FA Hurtado JA \& González E .(2021). Using robots with storytelling and drama activities in science education. Education Sciences, 11(7): 329. https://doi.org/10.3390/educsci11070329

Castro E Cecchi F Salvini P Valente M Buselli E Menichetti L Calvani A \& Dario P .(2018). Design and impact of a teacher training course, and attitude change concerning educational robotics. International Journal of Social Robotics, 10:669-685. https://doi.org/10.1007/s12369-018-0475-6

Cruz-Martín A Fernández-Madrigal JA Galindo C González-Jiménez J Stockmans-Daou C \& Blanco-Claraco JL (2012). A LEGO Mindstorms NXT approach for teaching at data acquisition, control systems engineering and real-time systems undergraduate courses. Computers \& Education, 59(3):974-988 https://doi.org/10.1016/j.compedu.2012.03.026

Damaševi cius R Narbutaite L Plauska I \& Blažauskas T (2017). advances in the use of educational robots in project-based teaching. TEM Journal, 6(2):342-348. https://doi.org/10.18421/TEM62-20

Daniela, L., Lytras, M.D. (2019). Educational - Robotics for Inclusive Education. Tech Know Learn 24, $219-225$. https://doi.org/10.1007/s10758-018-9397-

De Koning BB \& Tabbers HK. (2011). Facilitating understanding of movements in dynamic visualizations: an embodied perspective. Educational Psychology Review, 23:501-521.

Eguchi A (2014). Educational robotics for promoting 21st century skills. Journal of Automation Mobile Robotics and Intelligent Systems, 8(1):5-11.

Goode J \& Margolis J .(2011). Exploring computer science: a case study of school reform. ACM Transactions on Computing Education, 11(21):15.

Janssen JB van der Wal CC Neerincx MA \& Looije R.( 2011). Motivating children to learn arithmetic with an adaptive robot game. International Conference on Social Robotics (pp. 153-162). Berlin: Springer.

Kim KH Choi HS \& Baek JE.( 2014). A study on the teachers' perception of school curriculum implementation about robot-based education in Korea concept of robot-based education. Advanced Science and Technology Letters, 59:105-108.

Kradolfer S Dubois S Riedo F Mondada F \& Fassa F .(2014). A sociological contribution to understanding the use of robots in schools: the Thymio robot. In M Beetz B Johnston \& MA Williams (eds). International conference on social robotics (pp. 217-228). Berlin: Springer.

Li K Li Y \& Franklin T .(2016). Preservice teachers' intention to adopt technology in their future classrooms. Journal of Education and Computer Research, 54:946-966.

Loncomilla P Ruiz-del-Solar J \& Martínez L .(2016). Object recognition using local invariant features for robotic applications: a survey. Pattern Recognition, 60:499-514.

Looije R Neerincx MA \& de Lange V.( 2008). Children's responses and opinion on three bots that motivate, educate and play. Journal of Physical Agents, 2:13-20.

Lu CM Kang S Huang SC \& Black JB .(2011). Building student understanding and interest in science through embodied experiences with LEGO robotics. In T Bastiaens \& M Ebner (eds.). Proceedings of World Conference on Educational Multimedia, Hypermedia and Telecommunications 2011 (pp. 2225-2232). Chesapeake: American Association for Artificial Intelligence.

Mataric MJ.( 2004). Robotics education for all ages. American Association for Artificial Intelligence Spring Symposium on Accessible, Hands-on AI and Robotics Education, 2004. [Online]Available at 
https://www.aaai.org/Papers/Symposia/Spring/2004/SS-04-01/SS04-01-004.pdf. Accessed 1 August 2021.

MacDonald A Huser C Sikder S \& Danaia L .(2020.) Effective early childhood STEM education: findings from the 'Little Scientists' evaluation. Early Childhood Education Journal, 48:353-363.

Mcclure ER Guernsey L Clements DH Bales SN Nichols J Michael NK-T \& Levine H .(2017). STEM starts early: grounding science, technology, engineering, and math education in early childhood. New York: Joan Ganz Cooney Center at Sesame Workshop.

Mondada F Chevalier M \& Riedo F .(2016). Pedagogical uses of Thymio II: how do teachers perceive educational robots in formal education? A study based on the Thymio robot. IEEE Robotics and Automation Magazine, $23: 16-23$

Mubin O Stevens CJ Shahid S Al Mahmud A \& Dong JJ .(2013). A review of the applicability of robots in education. Journal of Technology for Education and Learning, 1:1-7.

Negrini L.(2020). Teachers' attitudes towards educational robotics in compulsory school [Gli Atteggiamenti Degli Insegnanti Della Scuola Dell'obbligo Nei Confronti Della Robotica Educativa]. Italian Journal of Educational Technology, 28:77-90. https://doi.org/10.17471/2499-4324/1136

Newley A Deniz H Kaya E \& Yesilyurt E. (2016). Engaging elementary and middle school students in robotics through hummingbird kit with Snap! visual programming language. Journal of Learning and Teaching in Digital Age, 1(2):20-26.

Park E Kim KJ \& Del Pobil AP .(2011). The effects of a robot instructor's positive vs. negative feedbacks on attraction and acceptance towards the robot in classroom. International Conference on Social Robotics (pp. 135-141). Berlin: Springer.

Ponce, P., Molina, A., Caudana, E.O.L. et al. (2019). Improving education in developing countries using robotic platforms. Int J Interact Des Manuf 13, 1401-1422. https://doi.org/10.1007/s12008-019-00576-5

Reich-Stiebert N \& Eyssel F .(2016). Robots in the classroom: what teachers think about teaching and learning with education robots. In A Agah J-J Cabibihan AM Howard MA Salichs \& H He (eds). Social robotics (pp. 671-680). Cham: Springer.

Saerbeck M Schut T Bartneck C \& Janse MD .(2010). Expressive robots in education: varying the degree of social supportive behavior of a robotic tutor. In Proceedings of the SIGCHI Conference on Human Factors in Computing Systems (pp. 1613-1622). New York: ACM.

Sangkawetai C Neanchaleay J Koul R \& Murphy E .(2020). Predictors of K-12 teachers' instructional strategies with ICTs. Technology, Knowledge, and Learning, 25: 149-177. https://doi.org/10.1007/s10758-018-9373-0

Schina D Valls-Bautista C Borrull-Riera A Usart M \& Esteve-González V.( 2021). An associational study: preschool teachers' acceptance and self-efficacy towards educational robotics in a pre-service teacher training program. International Journal of Educational Technology in Higher Education, 18(28):1-20.

Sisman B \& Kucuk S .(2019). An educational robotics course: examination of educational potentials and preservice teachers' experiences. International Journal of Research in Education and Science, 5(2):510-531.

Szafir D \& Mutlu B .(2012). Pay attention!: designing adaptive agents that monitor and improve user engagement. Proceedings of the SIGCHI Conference on Human Factors in Computing Systems (pp. 11-20). New York: ACM.

Tang ALL Tung VWS \& Cheng TO .(2020). Teachers' perceptions of the potential use of educational robotics in management education. Interactive Learning Environments. https://doi.org/10.1080/10494820.2020.1780269

Tocháček D Lapeš J \& Fuglík V.( 2016). Developing technological knowledge and programming skills of secondary schools students through the educational robotics projects. Procedia - Social and Behavioral Sciences, 217:377-338. https://doi.org/10.1016/j.sbspro.2016.02.107

Vilorio D.( 2014). STEM 101: Intro to tomorrow's jobs. Occupational Outlook Quarterly. https://www.bls.gov/careeroutlook/2014/spring/art01.pdf

Williams ME.( 2017). An examination of technology training experiences from teacher candidacy to in-service professional development. Journal of Instructional Pedagogies, 19:1-20. [Online]Available at https://files.eric.ed.gov/fulltext/EJ1158372.pdf. Accessed 1 August 2021.

Xia L \& Zhong BA. (2018). Systematic review on teaching and learning robotics content knowledge in K-12. Computers and Education, 127:267-282. https://doi.org/10.1016/j.compedu.2018.09.007

Y1ldırım B . (2021). Preschool STEM activities: preschool teachers' preparation and views. Early Childhood Education Journal, 49:149-162. https://doi.org/10.1007/s10643-020-01056-2 